\title{
The Effect of Circuit Training on Concentration of Medical Students in Diponegoro University
}

\author{
Tiwik Budi Hastari ${ }^{1}$, Zainal Muttaqin², Dimas Sindhu Wibisono ${ }^{3}$, Yuriz Bakhtiar² \\ ${ }^{1}$ Undergraduated program, Faculty of Medicine, Diponegoro University, Semarang, Indonesia \\ 2Department of Physiology, Faculty of Medicine, Diponegoro University, Semarang, Indonesia \\ ${ }^{3}$ Department Urology, Faculty of Medicine, Diponegoro University, Semarang, Indonesia
}

Keywords:

Circuit Training

Concentration Level Digit

Symbol Substitution Test

*)Correspondence to: yuriz_b@fk.undip.ac.id

Article history:

Received 07-05-2020

Accepted 31-05-2020

Availableonline $01-07-2020$

\begin{abstract}
Background: Concentration has an important role that influences the success of the learning process. The higher the concentration of students in learning, the more effective learning and teaching processes are carried out. One of the benefits of exercise is the improvement of concentration. Lack of time and motivation to do physical exercise are some reasons why people do less exercise. Circuit Training is an exercise that does not require much time and is becoming a trend now.

Objective: To find out the effect of the Circuit Training on the concentration level of students at Medical Faculty of Diponegoro University.

Methods: This research was a quasi-experimental study with pre and post- test design, where research subjects were divided into two groups, there are the control group and the treatment group. The research subjects were

28 male students at Medical Faculty of Diponegoro University. The treatment group had given Circuit Training for six weeks. In one week there were three meetings where each training session was done in 3 circuits/cycle and each circuit consisted of 8 movements. The indicator assessed in this study was the level of concentration measured using the Digit Symbol Substitution Test (DSST) before and after Circuit Training for six weeks. The results were analyzed using SPSS.

Results: The score of concentration in the treatment group increased with a pre-test score of $64,93 \pm 6,38$ and post-test score 76,29 $\pm 5,74$. Significant result $(p=0.001)$ were obtained in the pre and post-test treatment groups.

Conclusion: Circuit training for six weeks can increase the concentration score of students at Medical Faculty of Diponegoro University.
\end{abstract}

DIMJ, 2020, 1(1), 1-4 DOI: https://doi.org/10.14710/dimj.v1i1.7746

\section{Introduction}

Concentration is the ability to filter out information that is not needed and focus attention on the information needed. ${ }^{1}$ Based on the words of origin, concentration means the ability to focus the mind on one subject, object or thought, and at the same time exclude from the mind every other unrelated thought, ideas, feelings and sensations. ${ }^{1}$ In addition to this understanding, concentration is also defined as the ability to maintain attention or attention in a longer period.
Concentration has an important role that influences the success of the learning process. ${ }^{2}$ During concentration, the mind focuses on the object of concentration, and only one thought occupies the mind. ${ }^{2}$ The higher the concentration of students in learning, the more effective learning and teaching processes are carried out. Vice versa, if the concentration is low, then the learning outcomes obtained will also be low. ${ }^{3}$

One way to improve the cognitive function of the brain is to do physical activity. Physical activity has an impact on neurogenesis in the 
hippocampus, the learning centre and brain memory. A higher number of brain cells will provide the capacity to learn more. ${ }^{4}$ Research also shows that physical activity can also increase blood flow to the brain or cerebral blood flow (CBF) so that cardiac output increases. Increased cardiac output causes the amount of blood flow pumped by the heart to increase per minute. ${ }^{5}$ Exercise can improve cerebrovascular function where there is an increase in blood flow to the brain accompanied by adequate oxygen input. ${ }^{6}$ Research also shows that exercise increases serum calcium levels which affect increased dopamine synthesis which can sharpen brain function and improve mood in learning. ${ }^{7}$

Circuit training is a form of physical activity that can affect the cognitive function of the brain. Conducting circuit training in young adult groups shows increased concentration and spatial memory. ${ }^{8}$

\section{Methods}

This study used quasi-experimental with pre and post-test control group design. The subjects were 28 male students in Medical Faculty of Diponegoro University with normal Body Mass Index and between the age of 18-22 years old. Subjects were determined by purposive sampling method with inclusion and exclusion criteria and are divided into two groups: control group and treatment group, where each group consists of 14 people. The treatment group will be given Circuit Training for six weeks. In one week there were three meetings where each training session was done in 3 circuits /cycle and each circuit consists of 8 movements.

The subjects have been measured for concentration before doing the exercise (pre-test) and after six weeks of the exercise (post-test). The indicator assessed in this study was the level of concentration measured using the Digit Symbol Substitution Test (DSST).

Ethical clearance was requested from the Medical and Health Research Ethics Commission (KEPK) of the Faculty of Medicine, Diponegoro University. Subjects was given a brief explanation of the purpose, benefits, research protocols, possible side effects, and an informed consent sheet.

Data analysis includes descriptive analysis and hypothesis. Dependent variables data (concentration) from each group were analyzed using paired T-test for normal distribution, and Wilcoxon for abnormal distribution. Intergroup dependent variables data were analyzed using unpaired T-test for normal distribution and Mann - Whitney for abnormal distribution. The value of the degree of significance is $p<0.05$.

\section{Result}

The level of concentration was measured using the Digit Symbol Substitution Test (DSST) which consists of 90 squares containing numbers that must be paired with the appropriate symbols for 90 seconds. The more boxes can be filled, the higher the value indicates a better concentration level. Subjects filled out the DSST sheet twice, there were during the pre-test where the data was taken before the start of the circuit training and during the post-test where the data was taken two days after the 6-week circuit training was completed. The measurement results were shown in the following table.

Table 1. Score of Digit Symbol Substitution

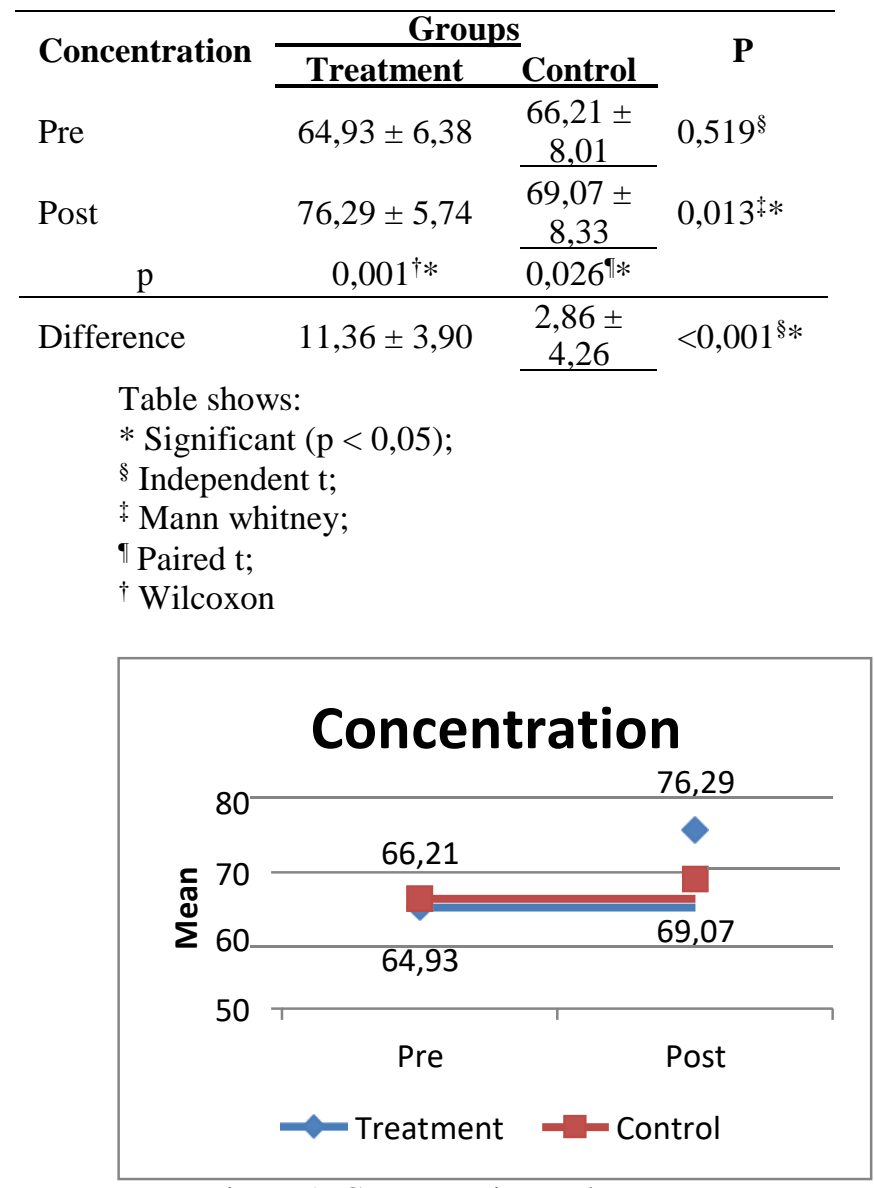

Figure 1. Concentration Values 
From this research, it can be concluded that circuit training improves the concentration as can be seen statistically in an increase of the post-test scores of the treatment group. The difference in pre-test and post-test scores for the two groups also obtained significant results $p=0.001$, which shows that circuit training in the treatment group can improve the concentration.

\section{Discussion}

The purpose of this study is to assess the concentration score of Diponegoro University Medical Faculty students between groups who were given intervention Circuit Training for six weeks and a control group or who did not do Circuit Training. The result data from the study were taken using the Digit Symbol Substitution Test (DSST), a sheet consisting of 90 boxes containing numbers that must be paired with the appropriate symbols for 90 seconds. The more boxes can be filled, the higher the value indicates a better concentration level. During the research, there were no subjects that dropped out, so that all subjects could undergo Circuit Training until done.

The results obtained from this study indicate a statistically significant increase in the level of concentration between before and after the treatment circuit training for six weeks in the treatment group. The increase in concentration was seen from the mean concentration value in the treatment group 64.93 (pre-test), increased by 11.36 to 76.29 (post-test). The control group that did not carry out the circuit training showed an increase in the level of concentration that was statistically lower than the treatment group. The mean in the control group was 66.21 (pre-test); increased by 2.86 to 69.07 (post-test).

This is consistent with the theory, which is during physical activity, several molecular systems can play a role in beneficial things to the brain it is the neurotrophic factors. Neurotrophic factors, especially Brain Derived Neurotrophic Factor (BDNF) can increase the resistance and growth of several types of neurons. ${ }^{9}$ BDNF acts as the main mediator of synaptic efficacy, nerve cell linkages, and nerve cell plasticity. The neurotrophin response mediated by physical activity may be limited to the motor and sensory systems of the brain. ${ }^{10}$

After physical activity, vasodilation of the blood vessels and an increase in heart rate will occur, causing blood circulation to reach the entire body, including the brain. ${ }^{11}$ An increase in blood circulation, causes a smooth supply of nutrients and oxygen, optimal brain function, and increases the activity of nerve growth factor (NGF). This nerve growth factor is a small protein that is important in the growth and maintenance of nerve cells. ${ }^{12}$

Physical activity can be one of the efforts to prevent cognitive dysfunction and dementia. Three mechanisms are involved, namely angiogenesis in the brain, synaptic reversal changes, and eliminating amyloid buildup. ${ }^{13}$ Mechanisms that explain the relationship between physical activity and cognitive functions such as blood pressure regulation, increase lipoprotein levels and endothelial nitric oxide production, and guarantee strong brain tissue perfusion. The direct effect on the brain is maintaining the neural structure and increasing the expansion of nerve fibres, synapses, and capillaries. ${ }^{4}$

Physical activity can also increase serum calcium levels which affect the increase in dopamine synthesis, which can sharpen brain function and improve mood in learning. ${ }^{9}$ Physical activity can increase growth hormone and norepinephrine. Norepinephrine works in modulation of nerve activity in the alerting process. Alerting (the first division of attention functions) is an attempt to maintain awareness of impending stimuli. ${ }^{5}$ The attention function needs the ability to concentrate on maintaining the function for an extended period. ${ }^{14}$

\section{References}

1. Slameto. Belajar Dan Faktor-Faktor Yang Mempengaruhinya. Jakarta: PT Rineka Cipta. 2014.

2. Julianto V, Dzulqaidah RP, Salsabila SN. Pengaruh Mendengarkan Murattal Al Quran Terhadap Peningkatan Kemampuan Konsentrasi. Psympathic J Ilm Psikol. 2014;1(2):120-9.

3. Halil A, Yanis A, Noer M. Pengaruh Kebisingan Lalulintas terhadap Konsentrasi Belajar Siswa SMP N 1 Padang. J Kesehat Andalas. 2015;4(1).

4. Blanton E, Honerlaw K, Kilian R, Sepe J. The effects of acute aerobic exercise on cognitive function in young adults. Madison, WI: University of Wisconsin-Madison; 2012.

5. Group DR in CN (DirecNet) S. The effects of aerobic exercise on glucose and counterregulatory hormone concentrations in 
children with type 1 diabetes. Diabetes Care. 2006;29(1):20-5.

6. Jacobs PL, Nash MS, Rusinowski JW. Circuit training provides cardiorespiratory and strength benefits in persons with paraplegia. Med Sci Sports Exerc. 2001;33(5):711-7.

7. Drollette ES, Scudder MR, Raine LB, Moore RD, Saliba BJ, Pontifex MB, et al. Acute exercise facilitates brain function and cognition in children who need it most: an ERP study of individual differences in inhibitory control capacity. Dev Cogn Neurosci. 2014;7:53-64.

8. Gmiat A, Micielska K, Kozłowska M, Flis DJ, Smaruj M, Kujach S, et al. The impact of a single bout of high intensity circuit training on myokines' concentrations and cognitive functions in women of different age. Physiol Behav. 2017;179:290-7.

9. Supervised KH, March AC. Effects of Circuit Training on Short-Term Memory \& Recall, Self-Perceived Academic Performance and Mood Written by Kevin Hayes Supervised by Aoife Cartwright Submitted in partial fulfilment of the requirements of the BA. 2016;(3).

10. Wood ER, Dudchenko PA, Robitsek RJ, Eichenbaum H. Hippocampal neurons encode information about different types of memory episodes occurring in the same location. Neuron. 2000;27(3):623-33.

11. Mayorga-Vega D, Viciana J, Cocca A. Effects of a circuit training program on muscular and cardiovascular endurance and their maintenance in schoolchildren. J Hum Kinet. 2013;37(1):153-60.

12. Hill WD, Davies G, Van De Lagemaat LN, Christoforou A, Marioni RE, Fernandes CPD, et al. Human cognitive ability is influenced by genetic variation in components of postsynaptic signalling complexes assembled by NMDA receptors and MAGUK proteins. Transl Psychiatry. 2014;4(1):e341.

13. Wang Y. Neuroinformatics models of human memory: Mapping the cognitive functions of memory onto neurophysiological structures of the brain. Int $\mathrm{J}$ Cogn Informatics Nat Intell. 2013;7(1):98-122.

14. Fan J, McCandliss BD, Sommer T, Raz A, Posner MI. Testing the efficiency and independence of attentional networks. J Cogn Neurosci. 2002;14(3):340-7. 